http://journal.unj.ac.id/unj/index.php/jpud

Volume 12 Edisi 2 November 2018

JURNAL PENDIDIKAN USIA DINI

DOI: https://doi.org/10.21009/JPUD.122

DOI: https://doi.org/10.21009/JPUD.122.04

\title{
PENGEMBANGAN MEDIA KOMIK ELEKTRONIK UNTUK MENINGKATKAN PEMAHAMAN KONSERVASI KELAUTAN ANAK USIA DINI
}

\author{
Erie Siti Syarah ${ }^{1}$, Elindra Yetti $^{2}$, lara fridani ${ }^{3}$ \\ Program Pendidkan Anak Usia Dini, Universitas Negeri Jakarta \\ E-mail: eriesitis_s2@mahasiswa.unj.ac.id ${ }^{1,}$ elindrayetti@unj.ac.id ${ }^{2}$, \\ lfridani@unj.ac.id ${ }^{3}$
}

\begin{abstract}
ABSTRAK
This study aims to develop electronic comic media as a medium to improve understanding of marine conservation in early childhood. The research method used is research and development with the ADDIE model. The data collection technique used is based on the result of expert validation and effectiveness test through quasi-experiment with data analysis of paired t-test statistic. The study involved children aged 7-8 years in urban areas as participants. The result of research and product development showed that (1) Electronic comic media significantly improved the understanding of marine conservation in children (2) the validity of electronic comics and electronic comics indicated by the test of marine conservation material expert $75 \%$ and media expert test 90,3\% with very category feasible. (3) The effectiveness of comic media is shown by the result of pre-test and post-test of children obtained by $t$-value $>t$-table, and Sig (2-tailed) $<0.05$ $(\alpha)$.
\end{abstract}

Keywords: Early Childhood, Electronic Comics, Marine Conservation,

Penelitian ini bertujuan untuk mengembangkan media komik elektronik sebagai sarana untuk meningkatkan pemahaman konservasi kelautan pada anak usia dini. Metode penelitian yang digunakan adalah penelitian dan pengembangan dengan model ADDIE. Tehnik pengumpulan data yang digunakan adalah hasil validasi pakar dan uji efektivitas melalui kuasi eksperimen dengan analisis data statistic paired t-test. Responden penelitian adalah anak usia 7-8 tahun di wilayah perkotaan. Hasil penelitian dan pengembangan produk yang dihasilkan menunjukkan bahwa (1) Media komik elektronik secara signifikan dapat meningkatkan pemahaman konservasi kelautan pada anak (2) kevalidan media komik elektronik ditunjukkan dengan hasil uji pakar materi konservasi kelautan 75\% dan uji pakar media 90,3\% dengan kategori sangat layak. (3) Keefektifan media komik ditunjukkan berdasarkan hasil pre-test dan post-test anak dengan hasil t-hitung lebih besar dari t-tabel, serta $\operatorname{Sig}(2$-tailed $)<0.05(\alpha)$.

Kata Kunci: Anak Usia Dini, Komik Elektronik, Konservasi Kelautan,

\section{PENDAHULUAN}

Indonesia memiliki wilayah perairan terbesar di dunia dimana duapertiga wilayahnya adalah perairan. Indonesia juga memiliki ribuan pulau dan mempunyai potensi keanekaragaman

hayati (biodiversity) yang sangat kaya, seperti Mangrove, Terumbu Karang, dan Padang Lamun (Departemen Kelautan dan Perikanan, 2008). Hal ini menjadikan masyarakat Indonesia sebagai masyarakat Masyarakat 
maritim Indonesia masih memiliki keterbatasan pengetahuan tentang potensi besar sumber daya hayati dan non hayati. (Winata 2010, p. 122) menemukan ada sekitar $44 \%$ penduduk di pesisir Pelabuhan Ratu Sukabumi yang belum mengetahui arti perlindungan dan konservasi sumber daya kelautan, dan sekitar 88 $\%$ penduduk belum memahami arti pelestarian sumber daya kelautan. Dutton mengobservasi 1600 responden dari berbagai wilayah di propinsi Lampung, Kalimantan Timur, Sulawesi Utara, dan Jabotabek. Penelitian tersebut menyimpulkan bahwa terdapat perbedaan yang mendasar dalam pengetahuan dan pengertian masyarakat yang menjadi kendala bagi keterlibatannya dalam program pengelolaan sumberdaya pesisir dan laut yang lebih baik (Dutton \& Kaswadji, 2001, p. 45)

Ada beragam isu yang terkait dengan pendidikan kelautan diantaranya adalah masalah kesadaran umum masyarakat terhadap lingkungan laut sehingga diperlukan pengembangan materi atau media pembelajaran baru.

Pendidikan laut adalah komponen pendidikan lingkungan yang signifikan, mengingat bahwa lautan mencakup sekitar $70 \%$ dari permukaan bumi.

Penelitian yang dilakukan oleh Whoythuyzen terkait dengan penerapan pendidikan konservasi kelautan pada anak usia dini, menghasilkan temuan bahwa Pendidikan konservasi kelautan mampu menumbuhkan nilai-nilai dan sikap siswa dalam membuat keputusan dalam hal pengelolaan dan pengembangan potensi wilayah pesisir menjadi lebih baik. Pengembangan potensi ini memerlukan jangka waktu yang tidak singkat, sehingga diperlukan pengembangan potensi wilayah masyarakat, dan pengenalan potensi lingkungan laut pada anak-anak usia dini dalam masyarakat tersebut. Hasil penelitian (Rosemery \& Wouthuyzen, 2015) di wilayah Kepulauan Seribu yang menunjukkan hasil belajar siswa yang rendah berdasarkan hasil pre-test dan posttest serta aktifitas guru dan siswa meningkat di setiap siklusnya dengan kategori sangat baik.

Anak usia dini adalah aktor saat ini dan masa depan yang berperan penting sebagai generasi penerus untuk memelihara dan mengelola sumber daya alam yang berkelanjutan, sehingga anak sejak usia dini perlu diberikan pemahaman konservasi kelautan. Pendidikan konservasi kelautan diperlukan baik oleh anak yang tinggal di daerah pesisir maupun yang bertempat tinggal di wilayah perkotaan mengingat Indonesia adalah negara maritim. Konservasi kelautan ini memerlukan kerjasama dan sinergi yang baik dari setiap bagian wilayah di Indonesia agar Sumber Daya Alam terjaga dengan baik. 
Pengembangan Media Komik Elektronik Erie, Elindra, \& Lara

Menurut (Lu \& Liu 2015) pendidikan kelautan untuk anak usia 7-8 tidak mudah untuk diterapkan karena latar belakang pengetahuan anak yang terbatas, sehingga perlu dicari solusi yang tepat untuk memberikan motivasi belajar dan meningkatkan pengetahuan anak.

Dunia teknologi digital (gadget) dapat menjadi salah satu alternative media pendidikan untuk anak mengingat anak di zaman sekarang pada umumnya sangat tertarik dengan teknologi. Penggunaan gadget pada anak usia dini tentu saja memiliki kelebihan dan kekurangan dengan demikian pendidik perlu mencari strategi yang tepat untuk meminimalkan keterbatasan tersebut.

Penggunaan teknologi gadget pada anak usia dini dikemukakan oleh beberapa ahli yang menyatakan bahwa anak secara alami belajar tentang lingkungan mereka melalui observasi, dimana dalam hal ini teknologi menawarkan fasilitas yang mudah diakses untuk memperluas wilayah dan jangkauan eksplorasi (Wang, Kinzie, Mcguire, \& Pan, 2010). Hasil penelitian tersebut menyarankan bahwa teknologi instruksional sedapat mungkin digunakan dalam Pendidikan anak usia dini, untuk memfasilitasi pemanfaatan sumber daya, mendukung proses pengembangan kognitif dan meta kognitif.

Penelitian tentang pentingnya penggunaan teknologi untuk anak usia dini telah dilakukan di beberapa negara maju. Salah satu contohnya adalah penelitian yang dilakukan di Amerika yang memberikan rekomendasi kebijakan yang mendorong orang tua untuk menggunakan teknologi media bersama anak-anak mereka. Riset dengan menggunakan sampel perwakilan nasional AS dari 2.326 orang tua anak-anak berusia 8 tahun ke bawah. Penelitian ini menguji faktor-faktor yang terkait dengan hubungan orang tua-anak di enam jenis media: buku, TV, komputer, video game, tablet, dan smartphone. Impikasi dari hasil penelitian tersebut adalah intervensi orangtua yang lebih tertuju untuk mendorong penggunaan bersama teknologi media (Connell, Lauricella, \& Wartella, 2015). Peneliti lain melakukan studi terkait dengan kegiatan membaca bersama antara orang tua dan anak dengan menggunakan buku elektronik, dimana terjadi interaksi yang baik antara anak dengan guru atau orang tua (Salmon, 2014). Program yang dilakukan antara lain melalui kegiatan membaca buku elektronik bersama, dimana orang dewasa sebagai pendidik dapat mengembangkan wawasan anak dalam berbagai bidang ilmu pengetahuan seperti konsep konservasi kelautan, dan mendukung perkembangan bahasa dan keaksaraan anak usia dini.

Penggunaan media buku komik elektronik yang menggunakan gambar dan teks, bisa memfasilitasi 
anak untuk mengenal berbagai gagasan. Menurut (Mcvicker, 2003), komik telah tersedia untuk anak usia dini sebagai media literasi yang memungkinkan guru merancang dan membuat sendiri komik dan menghubungkannya dengan tema pembelajaran. Komik juga memungkinkan guru untuk menyajikan informasi berulang dengan cara baru.-Cara lain yang popular terkait dengan penggunaan komik di kelas adalah dengan memberi kesempatan pada anak untuk membuat komik mereka sendiri (Nurgiyantoro, 2005).

Chen dan kawan-kawan melakukan penelitian terhadap 89 anak di Sekolah Dasar, kelas awal, di Taoyuan City, Taiwan. Para ahli tersebut meneliti sistem pembelajaran situasional dengan menggunakan permainan komik digital yang dirancang untuk membantu siswa belajar melalui penulisan naskah dalam kelompok. Hasil penelitian membuktikan bahwa siswa dari kelompok eksperimen memiliki motivasi belajar yang lebih tinggi secara signifikan dibandingkan dengan kelompok kontrol yang diajar menggunakan metode pengajaran tradisional (Fan \& Chang, 2018).

Berdasarkan hasil penelitian serta fakta permasalahan yang berkaitan dengan teknologi dan media pembelajaran anak usia dini, maka perlu dilakukan penelitian tentang pengembangan media komik elektronik untuk meningkatkan pemahaman konservasi kelautan. Komik elektronik merupakan media teknologi masa kini, yang selain dirancang untuk meningkatkan pemahaman konsep pengetahuan anak usia dini, juga merupakan media pembelajaran yang menarik minat anak. Kebanyakan buku elektronik di lapangan, belum menyajikan pengetahuan dalam bentuk komik. Penelitian ini berbeda dengan penelitian-penelitian sebelumnya, dimana peneliti menggunakan komik elektronik untuk menyajikan pengetahuan konservasi kelautan yang belum banyak dikembangkan pada saat ini. Selain itu, komik elektronik diharapkan dapat menjadi salah satu wadah teknologi yang dapat digunakan untuk mendidik dan meningkatkan pemahaman konsep anak tentang konservasi kelautan dengan cara yang menyenangkan.

\section{KAJIAN TEORITIK}

\section{Konservasi Kelautan}

Program sains dalam pendidikan anak usia dini didasarkan pada gagasan bahwa anak memiliki banyak kesempatan untuk menangkap dan membangun makna, kemudian melakukan pengamatan, mengambil kesimpulan, mengklasifikasi, membuat hipotesis, dan menjelaskan kembali gagasan tersebut kepada banyak orang. Menurut (Kellough, 1996) proses berpikir dan pembentukan konsep saat anak belajar merupakan hasil 
Pengembangan Media Komik Elektronik Erie, Elindra, \& Lara

pengetahuan sains (ilmu biologi dan fisik), dimana mereka mengeksplorasi dan bereksperimen dengan lingkungan mereka. Saat bermain sains, anak usia dini mengembangkan kemampuan untuk berpikir, merasakan masalah, dan menemukan cara untuk memecahkannya.

Konservasi adalah pengelolaan sumber daya alam hayati yang pemanfaatannya dilakukan secara bijaksana untuk menjamin kesinambungan persediaannya dengan tetap memelihara dan meningkatkan kualitas keanekaragaman dan nilainya (Mulyana dan Dermawan, 2008, p. 37). (Rachman, 2012)menyatakan tentang urgensi kekuatan besar yang dibutuhkan dalam melakukan gerakan konservasi alam. Konservasi kelautan tidak bisa dilakukan oleh masyarakat di sekitar pesisir dan laut saja, namun perlu dukungan masyarakat di perkotaan dalam konservasi laut, diantaranya adalah melalui perubahan gaya hidup yang dapat mencegah kerusakan laut Dengan adanya peran masyarakat di berbagai kalangan, maka kegiatan konservasi alam dapat terlaksana lebih mudah efisien dan efektif.

\section{Media Komik Elektronik}

Menurut Nurgiyantoro, sebagai sebuah bacaan komik hadir dengan keunikannya sendiri, dengan deretan gambar dalam panel-panel (kotak) gambar beserta sedikit tulisan tangan yang ditempatkan dalam balon-balon (Nurgiyantoro, 2005, p. 408). Jumlah tulisan yang sedikit pada komik memiliki manfaat bagi anak diantarnya mengurangi kelelahan pada mata anak saat membaca tulisan dan memberikan lebih banyak gambar yang bersifat informatif. Hal ini juga dengan mempertimbangkan kemampuan anak usia dini yang lebih sering menatap gambar pada komik daripada tulisan.

Para ahli telah mempromosikan penggunaan komik dan buku bergambar (comics and illustrated trade books /CTBs) saat mengajar sains untuk memperkuat pemahaman anak terhadap konsep, praktik, dan cara ilmuwan melakukan sains (Ardasheva \& Bowden, n.d.). Minat anak terhadap buku komik telah diteliti sejak lama, diantaranya oleh (Hurlock, 1980), yang menyatakan bahwa terlepas dari tingkat kecerdasan, hampir semua anak menyukai buku komik, baik yang bersifat lelucon maupun petualangan. Buku komik menarik karena menyenangkan, menggairahkan, mudah dibaca dan merangsang imajinasi anak.

Istilah komik elektronik disebut juga dengan komik digital. Perkembangan teknologi khususnya dalam dunia digital berimbas pada dunia komik, yang muncul dalam wujud komik elektronik/ digital. Dalam penelitian ini, aplikasi Comic Life digunakan dalam pengembangan media Komik Elektronik untuk 
menggabungkan gambar animasi dengan gambar nyata ("Comic life Plasq," n.d.).

Berdasarkan berbagai pendapat tentang media pembelajaran yang sudah dijelaskan di atas, maka dapat disimpulkan bahwa media Komik Elektronik, merupakan Media pembelajaran yang berjenis multimedia berbasis komputer, yang dibuat dengan menggunakan aplikasi comic life, berbentuk seperti buku elektronik yang disajikan dalam bentuk panel-panel dan balon-balon teks sederhana, dengan menggunakan gambar atau foto-foto yang disusun menjadi komik anak usia dini yang menyenangkan.

\section{METODOLOGI PENELITIAN}

Studi ini menerapkan penelitian dan pengembangan Media Komik Elektronik dengan menggunakan model ADDIE. Branch mengembangkan Instructional Design (Desain Pembelajaran) dengan pendekatan ADDIE, yang merupakan perpanjangan dari Analysis, Design, Development, Implementation dan Evaluation (Branch, 2009, p. 12).

\section{Tempat Penelitian}

Penelitian dan pengembangan media Komik Elektronik ini dilaksanakan pada kelompok anak usia 8 tahun (kelas II) pada Sekolah Dasar Islam Terpadu (SDIT) Al Hikmah dan Madrasah Ibtidaiyah
Assya'addaturrain di Wilayah Kota Tangerang Selatan.

\section{Subyek Penelitian}

Subyek penelitian dan pengembangan Media Komik Elektronik adalah anak usia 7-8 tahun yang tinggal di wilayah yang tidak berdekatan dengan daerah pesisir dan laut.

\section{Teknik Analisis Data}

Hasil uji efektifitas media Komik Elektronik menggunakan Teknik pengumpulan data dengan metode kuasi eksperimen dan dianalisa dengan analisa statistik uji-t berpasangan (paired $t$-test).

\section{HASIL DAN PEMBAHASAN}

\section{Hasil}

Penelitian ini menghasilkan produk media Komik Elektronik untuk meningkatkan pemahaman konservasi kelautan pada anak usia 7-8 tahun di wilayah Kota Tangerang Selatan. Tahapan dari penelitian dan pengembangan media Komik Elektronik meliputi:

\section{Draft 1}

Hasil pengembangan draft awal merupakan draft yang disusun dari hasil analisis kebutuhan dan studi literatur yang dilakukan sehingga menghasilkan sebuah draft 1. Media pada draft 1 ini di uji coba pakar untuk menghasilkan Model draft 2.

\section{Draft 2}

Draft 2 merupakan revisi hasil uji coba kelompok kecil, revisi 
Pengembangan Media Komik Elektronik Erie, Elindra, \& Lara

pengembangan draft 2 akan menghasilkan model draft3.

\section{Draft 3}

Pada pengembangan draft 3 dilakukan uji coba kelompok besar serta hasil dari revisi menjadi draft final yang disiapkan untuk uji efektifitas media.

\section{Draft Final}

Hasil dari pengembangan media Komik Elektronik menghasilkan draft final untuk kemudian dilakukan uji efektifitas media:

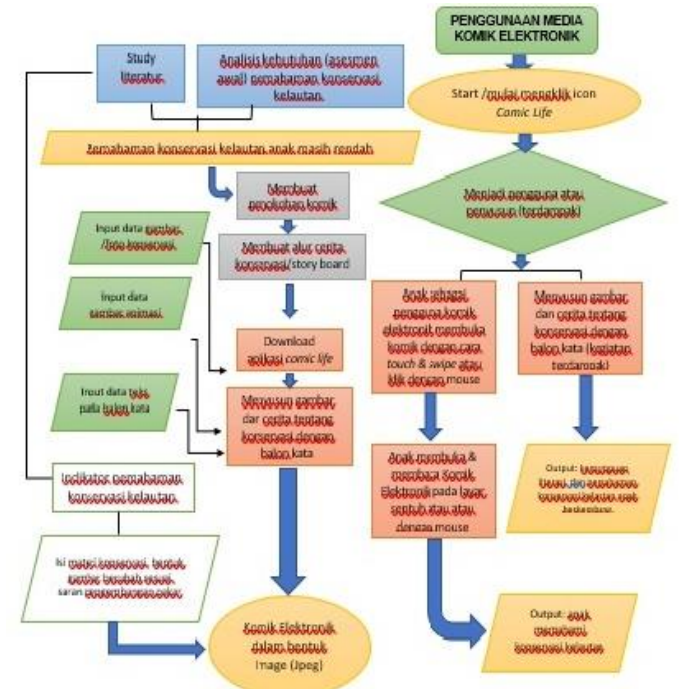

Gambar 1. Draft Final Model Konseptual Media Komik Elektronik

\section{Kelayakan Media Komik \\ Elektronik}

\section{Uji validasi pakar}

Pakar yang terlibat merupakan pakar media, sains, konservasi, Bahasa dan Pendididkan anak usia dini.

Tabel 1. Presentase Validasi Pakar

\begin{tabular}{ccccc}
\hline No & Pakar & Hasil Angket & Presentase & $\begin{array}{c}\text { Keterangan } \\
\text { Kelayakan } \\
\text { Media }\end{array}$ \\
\hline 1 & Media & $47 / 52 \times 100 \%$ & $90,38 \%$ & Sangat Layak \\
2 & Pendidikan Anak Usia Dini & $36 / 36 \times 100 \%$ & $100 \%$ & Sangat Layak \\
3 & Kelautan (Konservasi) & $23 / 32 \times 100 \%$ & $72 \%$ & Layak \\
4 & Biologi (Sains) & $24 / 32 \times 100 \%$ & $75 \%$ & Layak \\
5 & Bahasa & $40 / 40 \times 100 \%$ & $100 \%$ & Sangat Layak \\
\hline
\end{tabular}

\section{Uji Empiris}

Uji empiris dilakukan melalui uji coba kelompok kecil, uji coba kelompok besar serta uji efektifitas.

\section{Efektifitas Media Komik Elektronik}

Uji efektifitas media Komik elektronik bertujuan untuk melihat peningkatan pemahaman konservasi kelautan pada anak usia 7-8 tahun melalui media komik elektronik. Peneliti juga melihat ada tidaknya perbedaan dalam pemahaman anak sebelum dan sesudah menggunakan media komik elektronik. Berikut nilai pre-test dan post-test pada uji efektifitas:

Tabel 2. Hasil Uji Efektifitas Pre-test \& Post-test

\begin{tabular}{|c|c|c|c|c|}
\hline No & Responden & $\begin{array}{c}\text { Skor } \\
\text { Pre-Test }\end{array}$ & $\begin{array}{c}\text { Skor } \\
\text { Post-Test }\end{array}$ & $\begin{array}{c}\text { Presentase } \\
\text { peningkatan }\end{array}$ \\
\hline 1 & R 1 & 28 & 36 & $14 \%$ \\
\hline 2 & R 2 & 30 & 37 & $11 \%$ \\
\hline 3 & R 3 & 40 & 45 & $8,3 \%$ \\
\hline 4 & R 4 & 37 & 49 & $20 \%$ \\
\hline 5 & R 5 & 41 & 52 & $18,3 \%$ \\
\hline 6 & R 6 & 35 & 41 & $10 \%$ \\
\hline 7 & R 7 & 39 & 52 & $21,6 \%$ \\
\hline 8 & R 8 & 35 & 44 & $15 \%$ \\
\hline 9 & R 9 & 37 & 53 & $26 \%$ \\
\hline 10 & R 10 & 39 & 51 & $20 \%$ \\
\hline 11 & R 11 & 35 & 54 & $31,6 \%$ \\
\hline 12 & R 12 & 38 & 53 & $25 \%$ \\
\hline 13 & R 13 & 40 & 53 & $21,6 \%$ \\
\hline 14 & R 14 & 37 & 44 & $11,6 \%$ \\
\hline 15 & R 15 & 39 & 55 & $26,6 \%$ \\
\hline 16 & R 16 & 31 & 43 & $13 \%$ \\
\hline 17 & R 17 & 35 & 56 & $35 \%$ \\
\hline 18 & R 18 & 36 & 41 & $8,3 \%$ \\
\hline 19 & R 19 & 40 & 55 & $25 \%$ \\
\hline 20 & $\begin{array}{l}\text { R } 20 \\
\text { n }\end{array}$ & 37 & 43 & $10 \%$ \\
\hline 21 & R 21 & 38 & 50 & $20 \%$ \\
\hline 22 & R 22 & 40 & 46 & $10 \%$ \\
\hline 23 & R 23 & 30 & 39 & $15 \%$ \\
\hline 24 & R 24 & 39 & 53 & $23,3 \%$ \\
\hline 25 & R 25 & 35 & 55 & $33.3 \%$ \\
\hline 26 & R 26 & 31 & 48 & $28,3 \%$ \\
\hline 27 & R 27 & 38 & 46 & $13 \%$ \\
\hline 28 & R 28 & 38 & 51 & $21,6 \%$ \\
\hline 29 & R 29 & 37 & 40 & $5 \%$ \\
\hline 30 & R 30 & 38 & 45 & $11,6 \%$ \\
\hline 31 & R 31 & 37 & 52 & $25 \%$ \\
\hline 32 & R 32 & 31 & 46 & $25 \%$ \\
\hline 33 & R 33 & 31 & 41 & $16,7 \%$ \\
\hline 34 & R 34 & 33 & 41 & $13,3 \%$ \\
\hline 35 & R 35 & 31 & 50 & $31,6 \%$ \\
\hline 36 & R36 & 31 & 38 & $\begin{array}{l}11,6 \% \\
11,6 \%\end{array}$ \\
\hline 37 & R 37 & 35 & 41 & $10 \%$ \\
\hline 38 & R 38 & 33 & 52 & $31,6 \%$ \\
\hline 39 & R 39 & 32 & 44 & $20 \%$ \\
\hline 40 & R 40 & 30 & 42 & $20 \%$ \\
\hline 41 & R 41 & 32 & 46 & $23,3 \%$ \\
\hline 42 & R 42 & 35 & 48 & $21,6 \%$ \\
\hline 43 & R 43 & 36 & 58 & $36,7 \%$ \\
\hline 44 & R 44 & 36 & 49 & $21,7 \%$ \\
\hline 45 & R 45 & 35 & 46 & $18,3 \%$ \\
\hline 46 & R 46 & 32 & 45 & $21,6 \%$ \\
\hline 47 & R 47 & 35 & 47 & $20 \%$ \\
\hline 48 & R 48 & 28 & 44 & $26,7 \%$ \\
\hline 49 & $\begin{array}{l}\text { R 49 } \\
\text {. }\end{array}$ & 35 & 45 & $16,7 \%$ \\
\hline
\end{tabular}


Jika $\mathrm{t}$ hit $=18,154587, \mathrm{t}$ tabel $=$ 2.660 maka, $18,154587>2.660$ $\rightarrow$ berarti t hit $>\mathrm{t}$ tabel, $\mathrm{H}_{0}$ ditolak, artinya $\mathrm{H}_{1}$ diterima, bahwa ada terdapat perbedaan yang signifikan antara sebelum menggunakan media komik elektronik (hasil pre-test) dan sesudah menggunakan media komik elektronik (hasil post-test) pada populasi ke 49 (responden dari SDIT Al-Hikmah). Jika menggunakan Sig (p-value) Sig. (2-tailed) $=1,93918 \mathrm{E}$ 23 Maka, $\quad 1,93918$ E-23 $<0,05$ $\mathrm{H}_{0}$ ditolak, artinya $\mathrm{H}_{1}$ diterima, bahwa ada terdapat perbedaan yang signifikan pada pre-test dan post-test.

\section{Pembahasan}

Kegiatan pre-test menunjukkan hasil skor dari pemahaman konservasi kelautan anak rendah yaitu rata-rata $58.5 \%$ pada anak usia 7-8 tahun di wilayah Kota Tangerang Selatan. Hal ini disebabkan oleh rendahnya sosialisasi Pendidikan kelautan serta terbatasnya media pembelajaran untuk meningkatkan pemahaman kelautan anak. Hasil penelitian (Wen \& Lu, 2013) menunjukkan bahwa pengetahuan dan sikap siswa terhadap konservasi lingkungan laut memiliki pengaruh yang signifikan terhadap perilaku. Hasil penelitian Dimopoulos memverifikasi bahwa modul pendidikan memiliki pengaruh yang signifikan terhadap tingkat kognitif dan sikap konservasi pada siswa (Dimopoulos \& Pantis, 2009).
Temuan setelah post-test menyatakan adanya peningkatan pada pemahaman konservasi kelautan dengan presentasi peningkatan tertinggi adalah $36.7 \%$, dengan skor nilai pada pre-test sebesar $60 \%$ dan pada post-test menjadi 96,7\%. Temuan ini membuktikan antusias anak terhadap media komik elektronik yang membuat anak tenggelam (Immerse) dalam keasyikan membaca komik dan melakukannya tanpa beban. Ketika anak bermain melalui media komik elektronik, yang menggabungkan gambar animasi dengan gambar nyata (real Image), anak dapat melihat hal konkrit yang memudahkan mereka untuk meningkatkan pemahaman dan wawasan mereka terhadap konservasi kelautan dalam waktu yang cukup singkat dan dengan prosentase peningkatan yang sangat sifgnifikan.

Suardi melakukan penelitian dengan menggunakan aplikasi Comic Life, untuk mengetahui keefektifan penggunaan aplikasi Comic Life melalui Kegiatan Membaca pada 32 Responden. Hasil penelitian menunjukan bahwa Comic Life berkontribusi besar terhadap pemahaman membaca siswa. Kesimpulan penelitian yaitu penggunaan Comic Life melalui Kegiatan membaca dalam pengajaran membaca sangat efektif untuk meningkatkan pemahaman membaca siswa (Suardi, 2014). 
Pengembangan Media Komik Elektronik Erie, Elindra, \& Lara

Hasil temuan lainnya adalah terkait dengan adanya perasaan excitement

(kegembiraan/ketertarikan) anak pada media komik elektronik. Menurut hasil wawancara dengan guru, pada dasarnya anak menyukai komik sebagai bacaan yang ringan. Mereka menjadi sangat excited ketika mengetahui komik tentang kelautan itu ada di dalam gadget, sehingga mendorong anak untuk tertarik dengan lautan dan selanjutnya memikirkan apa yang harus dilakukan untuk menjaganya.

Studi (Hartley, Thompson, \& Pahl, 2015) meneliti pehamanan 176 anak-anak sekolah Inggris (usia 8-13 tahun) dan menguji dampak dari intervensi pendidikan. Hasilnya adalah anak-anak secara signifikan lebih peduli, memiliki pemahaman yang lebih baik tentang penyebab dan dampak negatif kerusakan alam, dan mendorong mereka terlibat dalam tindakan untuk mengurangi potensi penyebab sampah laut.

Temuan penting lain dari hasil penelitian dan pengembangan Media Komik Elektronik adalah dibutuhkannya fasilitas teknologi digital pada sekolah dasar saat ini. Untuk penerapan dan penggunaan media komik elektronik dapat disesuaikan dengan kebutuhan anak, apakah pengguna berada pada kelompok kecil atau besar, sedangkan format media komik elektronik dapat disesuaikan. 
Dimopoulos, D. I., \& Pantis, J. D. (2009). Planning Educational Activities and Teaching Strategies On Constructing a Conservation Educational Module, 4(4), 351364.

Dutton, I. M., \& Kaswadji, R. F. (2001). sikap dan persepsi masyarakat mengenai sumberdaya pesisir dan laut di indonesia. Jurnal Pesisir \& Lautan (Indonesian Journal of Coastal and Marine Resources), 3(3), 1-60. Retrieved from http://www.crc.uri.edu/download/J urnalPLVol3No3-O.pdf

Fan, G. C. C., \& Chang, C. C. Y. (2018). Promoting autonomy and ownership in students studying English using digital comic performance-based learning. Educational Technology Research and Development. https://doi.org/10.1007/s11423018-9597-7

Hartley, B. L., Thompson, R. C., \& Pahl, S. (2015). Marine litter education boosts children, $\mathrm{s}$ understanding and self-reported actions. Marine Pollution Bulletin, 90(1-2), 209-217. https://doi.org/10.1016/j.marpolbul .2014.10.049

Hurlock, E. B. (1980). Psikologi Perkembangan, Suatu Pendekatan Sepanjang Rentang Kehidupan. Jakarta: Erlangga.

Kellough, R. D. (1996). Integrating Mathematics and Science for Kindergarten and Primary Children. New Jersey: Prentice Hall. Inc.

Mcvicker, C. J. (2003). for Learning to Read, 85-89. https://doi.org/10.1598/RT.61.1.9

Nurgiyantoro, B. (2005). Sastra Anak; Pengantar Pemahaman Dunia Anak. yogyakarta: Gadjah Mada University.

Rachman, M. (2012). Konservasi nilai dan warisan budaya. Indonesian
Journal of Conservation, 1(1), 30 39.

Rosemery, S., \& Wouthuyzen, M. (2015). pendidikan konservasi sumber daya wilayah pesisir untuk siswa usia dini di sdn pulau pari 01 pagi kepulauan seribu selatan, 339-347.

Salmon, L. G. (2014). Factors that Affect Emergent Literacy Development When Engaging with Electronic Books, 85-92. https://doi.org/10.1007/s10643013-0589-2

Suardi. (2014). the implementation of 'comic life' through directed reading activities to increase students' reading comprehension. Ethical Lingua, 1(2), 30-43.

Wang, F., Kinzie, M. B., Mcguire, P., \& Pan, E. (2010). Applying Technology to Inquiry-Based Learning in Early Childhood Education. Early Childhood Educ J, 381-389. https://doi.org/10.1007/s10643-0090364-6

Wen, W., \& Lu, S. (2013). Marine environmental protection knowledge, attitudes, behaviors , and curricular involvement of Taiwanese primary school students in senior grades, 19(5), 600-619.

Winata, A. (2010). Peran masyarakat pesisir dalam penerapan strategi konservasi sumberdaya laut ( kasus di kelurahan palabuhanratu, kecamatan palabuhanratu , kabupaten sukabumi ). Jurnal Matematika, Sains, Dan Teknologi, 11(2), 122-132. 